\title{
Short communication: High frequency of $\beta$-lactam-resistant Staphylococcus aureus in artisanal coalho cheese made from goat milk produced in northeastern Brazil
}

\author{
B. B. Aragão, ${ }^{1 *}$ S. C. Trajano, ${ }^{1}$ J. G. Silva, ${ }^{1}$ B. P. Silva, ${ }^{1}$ R. P. Oliveira, ${ }^{1}$ J. W. Pinheiro Junior, ${ }^{1}$ R. M. Peixoto, ${ }^{2}$ \\ and R. A. Mota ${ }^{1}$ \\ ${ }^{1}$ Universidade Federal Rural de Pernambuco (UFRPE), CEP. 52171-900, Recife, PE, Brazil \\ ${ }^{2}$ Instituto Federal de Educação, Ciência e Tecnologia do Sertão Pernambucano (IFPE), CEP. 56316-686, Petrolina, PE, Brazil
}

\section{ABSTRACT}

Reports of $\beta$-lactam-resistant Staphylococcus aureus in artisanal goat cheese are increasing, and this phenomenon is relevant to public health. The objective of the present study was to determine the prevalence of $S$. aureus strains carrying the blaZ and mecA resistance genes, as well as the genes encoding the staphylococcal enterotoxins SEA, SEB, SEC, SED, SEE, and TSST-1 in artisanal coalho cheese made from goat milk produced in northeastern Brazil. We used biochemical and molecular tests to characterize $54 \mathrm{~S}$. aureus isolates found in artisanal coalho cheese collected from commercial establishments producing animal products in 11 municipalities of Pernambuco State, Brazil. A PCR analysis revealed that $42.6 \%(23 / 54)$ of the isolates were positive for the blaZ gene, and $7.4 \%$ (4/54) were resistant to methicillin by phenotypic testing. We did not detect mecA or any genes encoding enterotoxins. The presence of $S$. aureus carriers of the blaZ gene and the identification of methicillin-resistant $S$. aureus strains are of concern for the health of consumers of this type of cheese.

Key words: antimicrobial resistance, blaZ gene, goat cheese, enterotoxin gene

\section{Short Communication}

Goat farming is one of the most important agricultural activities in the northeast region of Brazil. The state of Pernambuco is the second-largest producer of goats in Brazil (IBGE, 2015). However, despite the economic importance of goat breeding, production systems have low adoption of technology and inadequate man-

Received December 13, 2018.

Accepted April 19, 2019.

*Corresponding author: breno.aragao100@hotmail.com agement, predisposing goat herds to diseases that cause economic losses. In addition to the economic impact of these factors, there is a risk to consumers of food of caprine origin, because pathogenic microorganisms, especially Staphylococcus aureus, can be transmitted from goat milk and its derivatives (Xing et al., 2016). This risk may result from direct secretion from the udder (Mørk et al., 2010) arise during one of the stages of obtaining and processing raw milk, or both (Argudin et al., 2010).

Staphylococcus aureus is one of the main pathogenic microorganisms that cause food poisoning and infections in humans and animals. It is an infectious agent of global importance to public health (Rahbar Saadat et al., 2014). Moreover, S. aureus has zoonotic potential, because it produces staphylococcal enterotoxins, contaminates food causing gastroenteritis (Xing et al., 2016), and is capable of forming a biofilm, which increases antimicrobial resistance and the risk of transmission and contamination of food (Akbas and Kokumer, 2015).

Several researchers have reported the significance of $S$. aureus in cheese made from goat's milk and the potential for staphylococcal enterotoxins to cause food poisoning in humans (Wieneke and Gilbert, 1987; Johler et al., 2015). In addition to the risk of food poisoning, certain strains of $S$. aureus carry resistance genes, including blaZ, which confer resistance to nonstable $\beta$-lactams (Zhang et al., 2001), and mecA, which causes resistance to certain $\beta$-lactam groups, such as cephalosporin (cefotaxime and ceftriaxone) and stable penicillins (oxacillin and methicillin; Rudkin et al., 2012).

Despite the importance of $S$. aureus in artisanal cheeses made with goat milk and its effect on public health, information on this subject in the national literature of Brazil is scarce. The objective of the present study was to determine the prevalence of $S$. aureus strains carrying blaZ and mecA resistance genes and staphylococcal enterotoxin genes encoding SEA, SEB, 

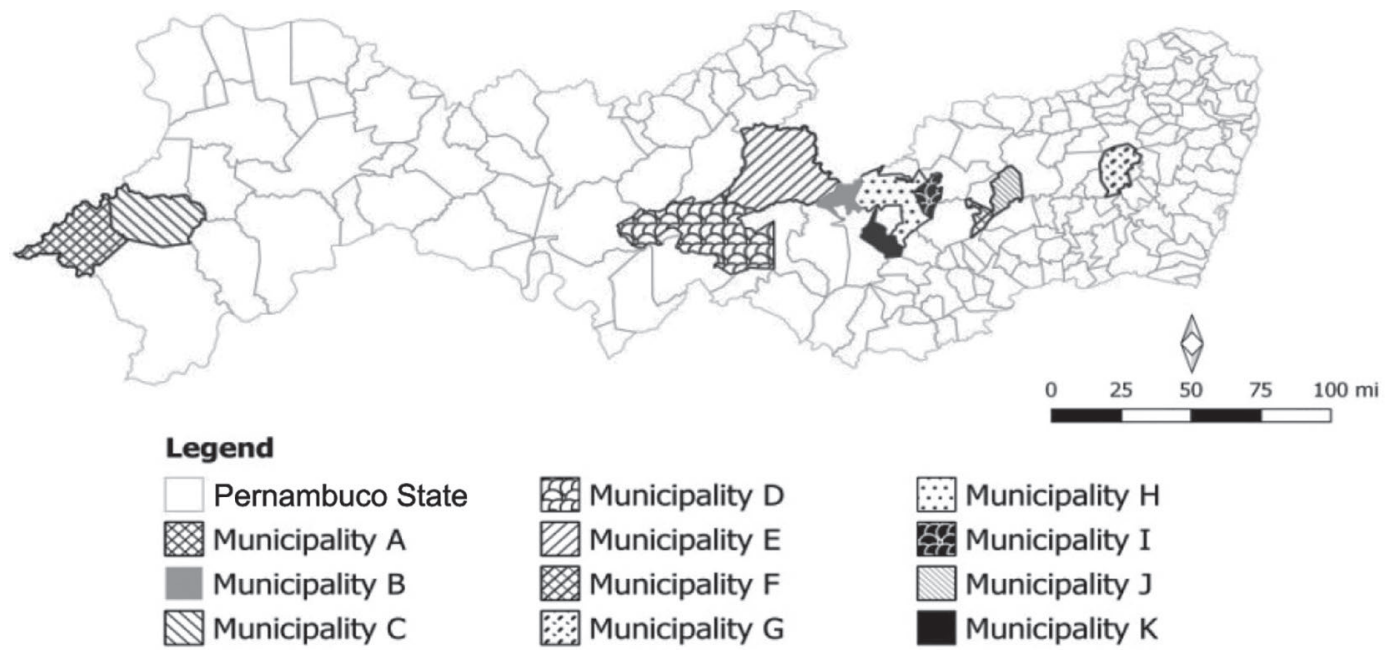

Figure 1. Distribution of samples by municipality in Pernambuco State, Brazil.

SEC, SED, SEE, and TSST-1 types in artisanal cheeses made from goat milk marketed in Pernambuco, Brazil.

Between March and August 2017, we collected 30 samples of artisanal coalho cheese made with goat milk from commercial establishments that produced animal products in 11 municipalities of Pernambuco, located in the regions of Sertão (municipalities A, B, C, D, and E) and Agreste (municipalities F, G, H, I, J, and K), as follows: 1 sample was collected in municipality A; 5 in municipality B; 2 in municipality C; 1 in municipality $\mathrm{D} ; 2$ in municipality $\mathrm{E} ; 1$ in municipality $\mathrm{F} ; 3$ in municipality G; 1 in municipality $\mathrm{H} ; 9$ in municipality I; 3 in municipality $\mathrm{J}$; and 2 in municipality $\mathrm{K}$ (Figure 1). Each sample weighed approximately $500 \mathrm{~g}$.

The isolation of $S$. aureus was performed according to the method recommended by Brazilian legislation (Brasil, 2003). We weighed $25 \mathrm{~g}$ portions from different parts of each cheese sample. We then transferred the fractions to sterile zipper storage bags containing $225 \mathrm{~mL}$ of sterile $0.85 \%$ saline solution. The samples were then homogenized for $60 \mathrm{~s}$ in a Stomacher blender (Seward, Bohemia, NY), and the resulting solutions were serially diluted to a factor of $10^{5}$. Aliquots of the diluted solutions $(0.1 \mathrm{~mL}$ each) were inoculated onto plates containing Baird Parker agar (Difco Laboratories Inc., Detroit, MI) enriched with egg yolk emulsion and potassium telluride (HiMedia, Mumbai, India) using a Drigalski loop. The plates were incubated at 35 to $37^{\circ} \mathrm{C}$ for $48 \mathrm{~h}$ (Brasil, 2003) and then the colonies on the Baird Parker agar were classified as typical or atypical.

A total of 158 typical $S$. aureus colonies were selected and subjected to DNA extraction (Table 1) according to the method proposed by Fan et al. (1995). To confirm the $S$. aureus species, we amplified the specific region of the $n u c$ gene according to the procedure of Kateete et al. (2010). We used the Staphylococcus aureus ssp. aureus strain ATCC 43300 as a positive control for detection of the nuc gene, and DNA-free water (Qiagen, Hilden, Germany) as a negative control. To detect the blaZ gene, we used the method described by Sawant et al. (2009). We used S. aureus ssp. aureus strain ATCC 29213 as a positive control, and DNA-free water (Qiagen) as a negative control. To detect the $m e c A$ gene, we used the primers described by Nakagawa et al. (2005) and the thermal profile described by Paterson et al. (2012). We used S. aureus ssp. aureus strain ATCC 43300 as a positive control and DNA-free water (Qiagen) as a negative control.

To detect genes encoding the SEA, SEB, and SED enterotoxins, we followed the method described by Becker et al. (1998), and to detect genes encoding the SEC, SEE, and TSTT-1 enterotoxins, we followed the method of Mehrotra et al. (2000). The following S. aureus strains were used as positive controls for the detection of enterotoxin-encoding genes: ATCC 13565 ( sea), ATCC 14458 (seb), ATCC 19095 (sec), FRI 361 (sed), ATCC 27664 (see), and N315 (tst1). We used DNAfree water (Qiagen) as a negative control. The strain $S$. aureus N315 used as positive control was provided by the Laboratory of Microbiology of Animal Products, Departamento de Tecnologia e Inspeção de Produtos de Origem Animal, Universidade Federal de Minas Gerais. The other reference strains used as positive controls were provided by the Laboratory of Infectious Diseases of Domestic Animals, Departamento de Medicina Veterinária, Universidade Federal Rural de Pernambuco.

To determine antimicrobial resistance, we carried out MIC tests with oxacillin $(\geq 4 \mu \mathrm{L} / \mathrm{mL})$ according to the CLSI (2015) method. We used the S. aureus ssp. aureus strain ATCC 43300 as a positive control 
for oxacillin resistance. The results of the qualitative diagnostic tests (PCR) are expressed as absolute and relative frequencies (Field, 2011).

Of the 158 typical colonies obtained in the microbiological analysis of artisanal coalho cheese samples made with goat milk, $54(34.1 \%)$ contained the $S$. aureus nuc gene. Other studies have already highlighted the economic and health effects of $S$. aureus as a pathogen in cheeses manufactured from goat milk (Akineden et al., 2008; Ganai et al., 2016).

We detected the blaZ gene in $42.6 \%(23 / 54)$ of the isolates. Resistance to antibiotics can occur by 1 of 2 mechanisms: the first is related to the production of $\beta$-lactamase associated with the blaZ gene (Lowy, 2003), and the second involves the production of penicillinbinding protein $2 \mathrm{a}$ (PBP2a), a protein that binds to $\beta$-lactams and is associated with the mecA gene (Guignard et al., 2005). We did not detect mecA in any of the isolates. Therefore, we believe resistance was due to production of $\beta$-lactamase. Furthermore, according to our phenotypic tests, $7.4 \%(4 / 54)$ of the isolates were resistant to oxacillin, and must therefore have contained methicillin-resistant $S$. aureus (MRSA).

The results we obtained for the occurrence of oxacillin-resistant isolates corroborated those obtained by França et al. (2012), who applied phenotype and genotype analysis to 171 isolates of Staphylococcus spp. in milk from goats with subclinical mastitis in the states of Bahia and Pernambuco. Of those isolates, 15.8\% (27/171) showed phenotypic resistance to oxacillin; the $m e c A$ gene was not detected, but the blaZ gene was present in $40.2 \%$ of the isolates. Peixoto et al. (2013) also carried out genotypic and phenotypic studies on isolates of Staphylococcus spp. in milk from goats with subclinical mastitis in Bahia State. In that study, 54.5\% of the isolates exhibited resistance; the mecA gene was not detected, but $33.3 \%$ of the Staphylococcus spp. isolates carried the bla $Z$ gene.

Unlike the results obtained in the present study and those mentioned above, the authors of other studies have reported the mecA gene in $S$. aureus isolated from goat milk and its products, such as cheese (Basanisi et al., 2016; Ganai et al., 2016). Moreover, mecA has been related to oxacillin resistance, as demonstrated in a study by Obaidat et al. (2017), in which it was detected in $11.9 \%(5 / 42)$ of expansion tank samples and $11.5 \%$ $(3 / 26)$ of milk samples. All the isolates carrying mecA were resistant to oxacillin, according to antimicrobial resistance tests.

Several hypotheses may explain the oxacillin resistance of $7.4 \%(4 / 54)$ of the $S$. aureus isolates observed in the present study, in the absence of mecA. The first hypothesis is related to the possible existence of oxacillin-resistant $S$. aureus strains that do not carry the mecA gene, which may be explained by the $\beta$-lactamase hyperproduction phenotype (Brown, 2001). Another hypothesis is that such isolates are carriers of a divergent form of the mecA gene called mec $C$, which also confers resistance to stable $\beta$-lactams (García-Álvarez et al., 2011). A third hypothesis depends on the existence of another oxacillin-resistant $S$. aureus strain such as MRSA ST130, which carries the homologous mecA gene but is not detected by conventional PCR assays for mecA because of its conformation (Pantosti, 2012).

There is major public health concern about MRSA strains, due to recent findings that such strains can colonize animals, especially cattle, and infect humans (Köck et al., 2011). They have also been identified in

Table 1. Primer sequences ${ }^{1}$ used in the reactions and amplicon sizes observed in the PCR

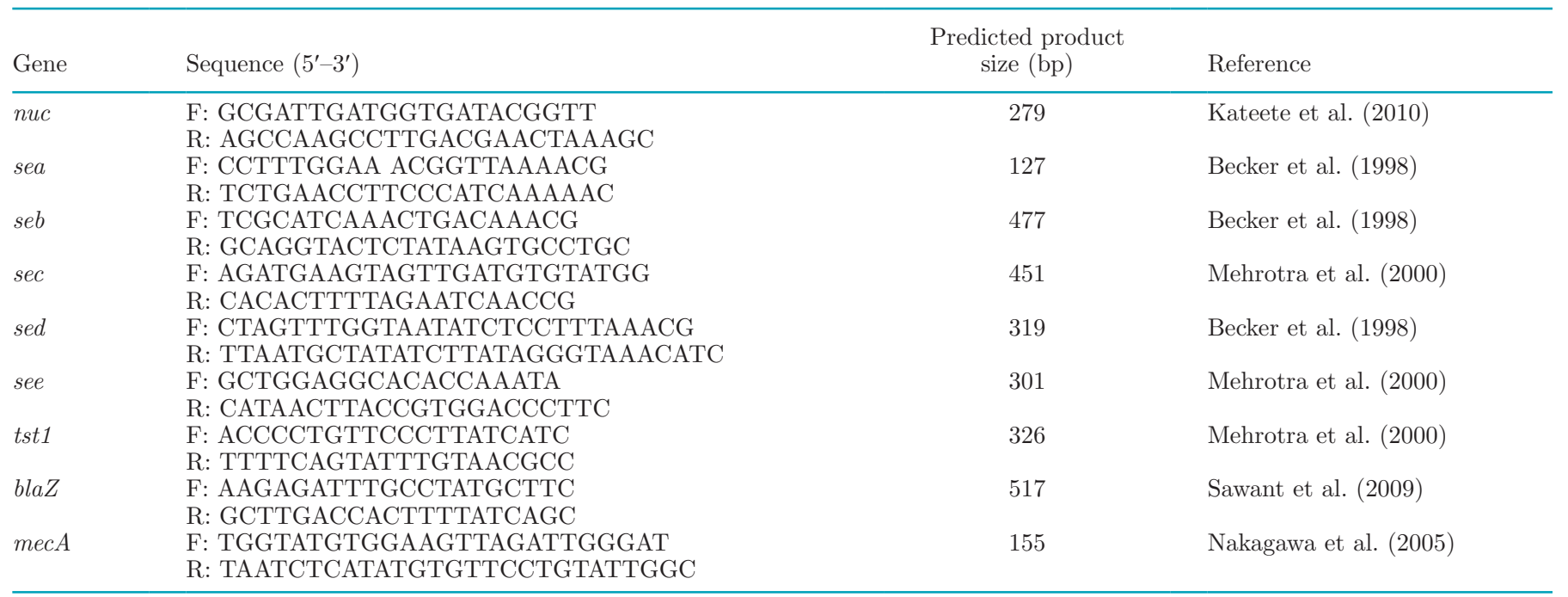

${ }^{1} \mathrm{~F}=$ forward $; \mathrm{R}=$ reverse. 
other animal species (Loeffler et al., 2005), including horses (Cuny et al., 2008) and swine (Gómez-Sanz et al., 2010). Studies that evaluate the possibility of MRSA transmission from goats to humans remain scarce, but in a study conducted in Austria, Loncaric et al. (2013) observed the possible transmission of ST398 MRSA strains from goats to humans.

The risk of transmission of methicillin-resistant strains of $S$. aureus from goat milk and cheese has been treated as a serious public and animal health problem affecting food production and safety (Ganai et al., 2016; Obaidat et al., 2017). Further studies on MRSA are needed in animal foods with respect to the genetic relationship between clones isolated from food and those that cause infections in humans (Kwon et al., 2005; Pantosti, 2012).

In the present study, we did not detect any enterotoxin-encoding genes (sea, seb, sec, sed, see, or tst1). Staphylococcus aureus is the bacterium most frequently involved in outbreaks of food poisoning, and a strain can produce more than one enterotoxin (Omoe et al., 2005). In general, studies have revealed a high prevalence of classical $S$. aureus genes in goat milk products, with the sec gene being the most frequently detected (Akineden et al., 2008; Xing et al., 2016).

Despite the absence of enterotoxin genes in the samples of the present study, these samples may still pose a risk for food poisoning, because we did not investigate other staphylococcal enterotoxin-encoding genes. The presence of $S$. aureus in cheese may be a concern for public health authorities, because it is associated with inadequate hygiene in the production and modification of foods (Argudin et al., 2010). Moreover, S. aureus carries antimicrobial-resistant genes of the $\beta$-lactam class and exhibits resistance to oxacillin in MIC tests.

The high prevalence of $S$. aureus carriers of the blaZ gene and the identification of methicillin-resistant strains are a health concern for consumers of this type of cheese. These results should also alert public health surveillance agencies to the poor quality of artisanal cheeses made with goat milk in this region of northeastern Brazil.

\section{ACKNOWLEDGMENTS}

The authors thank Marcelo Resende de Souza from Departamento de Tecnologia e Inspeção de Produtos de Origem Animal, Universidade Federal de Minas Gerais (UFMG) for providing $S$. aureus N315 strain as a positive control. The corresponding author thanks the Fundação de Amparo a Ciência e Tecnologia do Estado de Pernambuco (FACEPE) for the scholarship provided.

\section{REFERENCES}

Akbas, M. Y., and T. Kokumer. 2015. The prevention and removal of biofilm formation of Staphylococcus aureus strains isolated from raw milk samples by citric acid treatments. Int. J. Food Sci. Technol. 50:1666-1672.

Akineden, Ö., A. A. Hassan, E. Scheneider, and E. Usleber. 2008. Enterotoxigenic properties of Staphylococcus aureus isolated from goats' milk cheese. Int. J. Food Microbiol. 124:211-216.

Argudin, M. Á., M. C. Mendoza, and M. R. Rodicio. 2010. Food poisoning and Staphylococcus aureus enterotoxins. Toxins (Basel) $2: 1751-1773$.

Basanisi, M. G., G. Nobili, G. La Bella, R. Russo, G. Spano, G. Normanno, and G. La Salandra. 2016. Molecular characterization of Staphylococcus aureus isolated from sheep and goat cheeses in southern Italy. Small Rumin. Res. 135:17-19.

Becker, K., R. Roth, and G. Peters. 1998. Rapid and specific detection of toxigenic Staphylococcus aureus: Use of two multiplex PCR enzyme immunoassays for amplification and hybridization of staphylococcal enterotoxin, exfoliative toxin genes, and toxic shock syndrome toxin 1 gene. J. Clin. Microbiol. 36:2548-2553.

BRASIL. Ministério da Agricultura, Pecuária e Abastecimento. 2003. Instrução Normativa $n^{\circ} 62$ de 26 de agosto de 2003. Oficializa os Métodos analíticos oficiais para análises microbiológicas para controle de produtos de origem animal e água. Brasília: Ministério da Agricultura, Pecuária e Abastecimento. Accessed Sep. 15, 2018. http://www.agricultura.gov.br/.

Brown, D. F. J. 2001. Detection of methicillin/oxacillin resistance in staphylococci. J. Antimicrob. Chemother. 48:65-70.

CLSI (Clinical and Laboratory Standards Institute). 2015. Performance Standards for Antimicrobial Susceptibility Testing. 23rd Informational Supplement. M100-S25. CLSI, Wayne, PA.

Cuny, C., B. Strommenger, W. Witte, and C. Stanek. 2008. Clusters of infections in horses with MRSA ST1, ST254 and ST398 in a veterinary hospital. Microb. Drug Resist. 14:307-310.

Fan, H. H., S. H. Kleven, and M. W. Jackwood. 1995. Application of polymerase chain reaction with arbitrary primers to strain identification of Mycoplasma gallisepticum. Avian Dis. 39:729-735.

Field, A. 2011. Descobrindo a estatística usando o SPSS. 2nd ed. Artmed, Porto Alegre, Brazil.

França, C. A., R. M. Peixoto, M. B. Cavalcante, N. F. Melo, C. J. B. Oliveira, J. L. A. Veschi, R. A. Mota, and M. M. Costa. 2012. Antimicrobial resistance of Staphylococcus spp. from small ruminant mastitis in Brazil. Pesqui. Vet. Bras. 32:747-753.

Ganai, A. W., S. K. Kotwal, N. Wani, M. A. Malik, R. Jeelani, S. Kour, and R. Zargar. 2016. Detection of mecA gene of methicillin resistant Staphylococcus aureus by PCR assay from raw milk. Indian J. Anim. Sci. 86:508-511.

García-Álvarez, L., M. T. Holden, H. Lindsay, C. R. Webb, D. F Brown, M. D. Curran, E. Walpole, K. Brooks, D. J. Pickard, C. Teale, J. Parkhill, S. D. Bentley, G. F. Edwards, E. K. Girvan, A. M. Kearns, B. Pichon, R. L. Hill, A. R. Larsen, R. L. Skov, S. J. Peacock, D. J. Maskell, and M. A. Holmes. 2011. Methicillinresistant Staphylococcus aureus with a novel mecA homologue in human and bovine populations in the UK and Denmark: A descriptive study. Lancet Infect. Dis. 11:595-603.

Gómez-Sanz, E., C. Torres, C. Lozano, R. Fernandez-Perez, C. Aspiroz, F. Ruiz-Larrea, and M. Zarazaga. 2010. Detection, molecular characterization, and clonal diversity of methicillin-resistant Staphylococcus aureus CC398 and CC97 in Spanish slaughter pigs of different age groups. Foodborne Pathog. Dis. 7:1269-1277.

Guignard, B., J. M. Entenza, and P. Moreillon. 2005. $\beta$-lactams against methicillin-resistant Staphylococcus aureus. Curr. Opin. Pharmacol. 5:479-489.

IBGE (Instituto Brasileiro de Geografia e Estatística). Produção da Pecuária Municipal. 2015. Accessed Sep. 10, 2018. http:// biblioteca.ibge.gov.br/visualizacao/periodicos/84/ppm_2015_v 43_br.pdf.

Johler, S., P. Giannini, M. Jermini, J. Hummerjohann, A. Baumgartner, and R. Stephan. 2015. Further evidence for staphylococcal 
food poisoning outbreaks caused by egc-encoded enterotoxins. Toxins (Basel) 7:997-1004.

Kateete, D. P., C. N. Kimani, F. A. Katabazi, A. Okeng, M. S. Okee, A. Nanteza, M. L. Joloba, and F. C. Najjuka. 2010. Identification of Staphylococcus aureus: DNase and mannitol salt agar improve the efficiency of the tube coagulase test. Ann. Clin. Microbiol. Antimicrob. 9:23-29.

Köck, R., K. Siam, S. Al-Malat, J. Christ-Mann, F. Schaumburg, K. Becker, and A. W. Friedrich. 2011. Characteristics of hospital patients colonized with livestock-associated meticillin-resistant Staphylococcus aureus (MRSA) CC398versusother MRSA clones. J. Hosp. Infect. 79:292-296.

Kwon, N. H., K. T. Park, J. S. Moon, W. K. Jung, S. H. Kim, J. M. Kim, S. K. Hong, H. C. Koo, Y. S. Joo, and Y. H. Park. 2005. Staphylococcal cassette chromosome mec (SCCmec) characterization and molecular analysis for methicillin-resistant Staphylococcus aureus and novel SCCmec subtype IVg isolated from bovine milk in Korea. J. Antimicrob. Chemother. 56:624-632.

Loeffler, A., A. K. Boag, J. Sung, J. A. Lind-Say, L. Guardabassi, A. Dalsgaard, H. Smith, K. B. Stevens, and D. H. Lloyd. 2005. Prevalence of methicillin-resistant Staphylococcus aureus among staff and pets in a small animal referral hospital in the UK. J. Antimicrob. Chemother. 56:692-697.

Loncaric, I., R. Brunthaler, and J. Spergsera. 2013. Suspected goat-tohuman transmission of methicillin-resistant Staphylococcus aureus sequence type 398. J. Clin. Microbiol. 51:1625-1626.

Lowy, F. D. 2003. Antimicrobial resistance: The example of Staphylococcus aureus. J. Clin. Invest. 111:1265-1273.

Mehrotra, M., G. Wang, and W. M. Johnson. 2000. Multiplex PCR for detection of genes for Staphylococcus aureus enterotoxins, exfoliative toxins, toxic shock syndrome toxin 1 , and methicillin resistance. J. Clin. Microbiol. 38:1032-1035.

Mørk, T., B. Kvitle, T. Mathisen, and H. J. Jørgensen. 2010. Bacteriological and molecular investigations of Staphylococcus aureus in dairy goats. Vet. Microbiol. 141:134-141.

Nakagawa, S., I. Taneike, D. Mimura, N. Iwakura, T. Nakayama, T. Emura, M. Kitatsuji, A. Fujimoto, and T. Yamamoto. 2005. Gene sequences and specific detection for Panton-Valentine leukocidin. Biochem. Biophys. Res. Commun. 328:995-1002.

Obaidat, M. M., A. E. Bani Salman, and A. A. Roess. 2017. High prevalence and antimicrobial resistance of mecA Staphylococcus aureus in dairy cattle, sheep, and goat bulk tank milk in Jordan.
Trop. Anim. Health Prod. 50:405-412. https://doi.org/10.1007/ s11250-017-1449-7.

Omoe, K., D. L. Hu, H. Takahashi-Omoe, A. Nakane, and K. Shinagawa. 2005. Comprehensive analysis of classical and newly described staphylococcal superantigenic toxin genes in Staphylococcus aureus isolates. FEMS Microbiol. Lett. 246:191-198.

Pantosti, A. 2012. Methicillin-resistant Staphylococcus aureus associated with animals and its relevance to human health. Front. Microbiol. 3:127.

Paterson, G. K., A. R. Larsen, A. Robb, G. E. Edwards, T. W. Pennycott, G. Foster, D. Mot, K. Hermans, K. Baert, S. J. Peacock, J. Parkhill, R. N. Zadoks, and M. A. Holmes. 2012. The newly described mecA homologue, mecALGA251, is present in methicillinresistant Staphylococcus aureus isolates from a diverse range of host species. J. Antimicrob. Chemother. 67:2809-2813.

Peixoto, R. M., R. M. Peixoto, A. P. P. Alves, L. J. S. Peixoto, A. M. Reges, and M. M. Costa. 2013. Genes de resistencia a antimicrobianos e producao de biofilme em Staphylococcus spp. isolados de caprinos leiteiros. Vet. Zootec. 20:343-344.

Rahbar Saadat, Y. A. A. Imani Fooladi, R. Shapouri, M. M. Hosseini, and Z. Deilami Khiabani. 2014. Prevalence of enterotoxigenic Staphylococcus aureus in organic milk and cheese in Tabriz, Iran. Iran. J. Microbiol. 6:345-349.

Rudkin, J. K., A. M. Edwards, M. G. Bowden, E. L. Brown, C. Pozzi, E. M. Waters, W. C. Chan, P. Williams, J. P. O'Gara, and R. C. Massey. 2012. Methicillin resistance reduces the virulence of healthcare-associated methicillin-resistant Staphylococcus aureus by interfering with the agr quorum sensing system. J. Infect. Dis. 205:798-806.

Sawant, A. A., B. E. Gillespie, and S. P. Oliver. 2009. Antimicrobial susceptibility of coagulase-negative Staphylococcus species isolated from bovine milk. Vet. Microbiol. 134:73-81.

Wieneke, A., and J. Gilbert. 1987. Comparison of four methods for the detection of staphylococcal enterotoxin in foods from outbreaks of food poisoning. Int. J. Food Microbiol. 4:135-143.

Xing, X., Y. Zhang, Q. Wu, X. Wang, W. Ge, and C. Wu. 2016. Prevalence and characterization of Staphylococcus aureus isolated from goat milk powder processing plants. Food Control 59:644-650.

Zhang, H. Z., C. J. Hackbarth, K. M. Chansky, and H. F. Chambers. 2001. A proteolytic transmembrane signaling pathway and resistance to beta-lactams in staphylococci. Science 291:1962-1965. 